\title{
PELATIHAN PENGGUNAAN APLIKASI CLASSDOJO SEBAGAI UPAYA PENINGKATAN PEMBELAJARAN JARAK JAUH BAGI GURU SD IT BINA BANGSA DI ERA KENORMALAN BARU
}

\author{
Jaka Wijaya Kusuma ${ }^{1)}$, Ulfi Jefrii ${ }^{2)}$, Endang Surnani ${ }^{3)}$, Ika Pratiwi ${ }^{4)}$, Ega \\ Kurniawan ${ }^{5}$ \\ ${ }^{1,2}$ Fakultas Keguruan dan Ilmu Pendidikan, Universitas Bina Bangsa \\ ${ }^{3,4,5}$ SD IT Bina Bangsa
}

\begin{abstract}
Abstrak
Era kenormalan Baru telah membawa perubahan pembelajaran yang berbasis kelas menjadi online dan jarak jauh. Guru dituntut meningkatkan kompetensi mereka terutama dalam pemilihan media pembelajaran yang inovatif. Upaya-upaya yang dapat membantu guru dalam meningkatkan kompetensi mereka dalam pembelajaran online bisa dilakukan melalui program pelatihan dan pendampingan salah satunya yang dikenalkan adalah penggunaan aplikasi classdojo. Artikel ini menggambarkan proses pelatihan dan hasil dari pelatihan penggunaan classdojo kepada guru SD IT Bina Bangsa. Hasilnya menunjukkan bahwa guru SD IT Bina Bangsa sudah mahir menggunakan Internet dan terbiasa dengan media pembelajaran jarak jauh, Antusias dan ketertarikan dalam pelatihan ini sangat tinggi ditunjukkan dari interaksi yang terjadi selama pelatihan, dan guru berharap ada kegiatan lebih lanjut dalam penggunaan classdojo sekaligus berharap bisa menjadi Tutor resmi classdojo.

Keywords: classdojo, Pembelajaran Jarak Jauh, Era Kenormalan Baru
\end{abstract}

\begin{abstract}
The new Normal era has brought the change of classroom-based learning to online and remotely. Teachers are required to increase their competence especially in the selection of innovative learning media. Efforts that can help teachers to improve their competence in online learning can be done through training programs and mentoring one of which is introduced is the use of the Classdojo application. This article illustrates the training process and results from the training of the Classdojo use to SD IT Bina Bangsa teachers. The results show that the teachers of SD IT Bina Bangsa are proficient to use the Internet and accustomed to the media distance learning, enthusiastic and interest in this training is very high demonstrated from the interactions that occurred during the training, and teachers hope there is further activity in the use of the Classdojo while hoping to become an official Tutor Classdojo.
\end{abstract}

Keywords: Classdojo, Distance Learning, New Normal Era

Correspondence author: jaka wijaya kusuma, jakawijayak@gmail.com, Serang, Indonesia 


\section{PENDAHULUAN}

Dalam menghadapi masa Kenormalan Baru, Guru dituntut untuk kembali tetap melaksanakan Pembelajaran Jarak Jauh. Yang terjadi dewasa ini, Pembelajaran di sekolah dibuat tetap berjalan dengan mengikuti aturan dan edaran dari pemerintah setempat. Sehingga para guru dibuat berpikir lebih bagaimana kegiatan pembelajaran tetap berjalan dengan sesuai aturan dan siswa-siswa pun tetap aktif melaksanakan Pembelajaran. Hal ini menuntut guru untuk berinovasi dalam hal pembelajaran, salah satunya menggunakan media pembelajaran yang di anggap efektif.

Permasalahannya, tidak semua siswa bisa di sama ratakan kebutuhannya. Terutama bagi Guru yang mengajar di Sekolah Dasar. Karena usia-usia sekolah dasar masih di anggap belum matang dan mandiri dalam menggunakan Platform-platform yang biasa dipergunakan oleh Guru lain di Sekolah menengah atau di Sekolah Akhir.

Dalam Pola Pikir usia anak pada tahap awal usia ditandai dengan ciri di antaranya: 1. Transductive reasoning, yakni pola pikir anak yang menghubungkan antara informasi awal dengan info lanjut, walaupun secara hubungan yang tidak secara langsung. 2. Ketidakjelasan kausal, yaitu pola pikir anak yang mengenal interaksi sebab akibat dari keadaaan namun interaksi yang terjadi bukan karena secara langsung maupun hubungan yang tidak logis sekalipun. 3. Perceptually bound, yaitu pola pikir anak dimana menilai sesuatu didasarkan atas apa yang dilihat atau didengar, lazimnya dalam dunia pendidikan, siswa lebih peka dengan apa yang diucapkan guru daripada orang lain, bahkan bapak ibunya sekalipun. 4. Mental experiment yaitu pola pikir anak yang merupakan hasil penelitian atau melakukan untuk menemukan info dari rasa penasaran dari persoalan yang anak temui. 5. Centration, yaitu pola pikir anak untuk memusatkan atensinya kepada ciri yang membuat tertarik menurut dirinya dan mentidak acuhkan ciri lainnya, 6. Egosentrisme, yaitu pola pikir anak terhadap hal yang dilihat oleh lingkungan dan menurut kehendak dirinya(Sobiruddin, 2020)

Dari penjelasan yang dsampaikan, jelaslah anak pada masa SD akan kesulitan jika Guru salah dalam menggunakan Media Pembelajaran. Terutama media pembelajaran yang bersifat Online.terlebih Pendidikan jarak jauh (PJJ) atau biasa disebut juga dengan Belajar dari Rumah (BDR), saat ini hampir semua para pelaku pendidikan menjadikannya salah satu solusi pembelajaran dalam menghadapi situasi Kenormalan Baru. Istilah Belajar dari Rumah tersebut sudah lama digaungkan bahkan diterapkan oleh para guru - guru di Indonesia pada pembelajaran yang notabene dalam hal ini lebih banyak dilakukan secara terpisah di luar kelas. Artinya disini berarti antara pemateri atau narasumber dan siswa atau peserta tidak sedang ada di satu ruangan yang sama (tidak terjadi interaksi langsung didalam kelas) bahkan waktunyanya pun bisa tidak bersamaan (Asinkron). Interaksi guru dan siswa dilakukan secara langsung maupun tidak langsung, misal dengan melakukan pesan lewat koneksi internet (langsung) maupun dengan berkirim Surat elektronik untuk perihal mengumpulkan tugas (tidak langsung). (Kusuma \& Hamidah, 2020)

Meskipun demikian, permasalahan di atas merupakan sebuah tantangan bagi Guru untuk berkreasi dan inovatif dalam melaksanakan Pembelajaran Jarak Jauh. Dengan semakin meningkatnya teknologi dan semakin bermunculan Platform-platform, maka peran Guru sangatlah penting dalam hal selektif memilih Platform yang dipakai. Teknologi seakan-akan memberikan kemudahan dalam segala bidang kehidupan, Termasuk dibidang pembelajaran(Kurniawan et al., 2020). Dan salah satu Aplikasi atau Platform yang penulis coba perkenalkan adalah Classdojo. Aplikasi ini akan membantu 
Pelatihan Penggunaan Aplikasi Classdojo Sebagai Upaya Peningkatan Pembelajaran Jarak Jauh Bagi Guru SD IT Bina Bangsa Di Era Kenormalan Baru ... (Jaka Wijaya Kusuma)

guru dalam menerapkan pembelajaran onlinenya. Aplikasi ini sangat ringan dan tidak sulit dalam mengaplikasikannya. Aplikasi ini bisa menjadi alternatif bagi guru untuk menerapkan pembelajaran jarak jauh yang selama ini terhalang oleh jarak dan kuota.

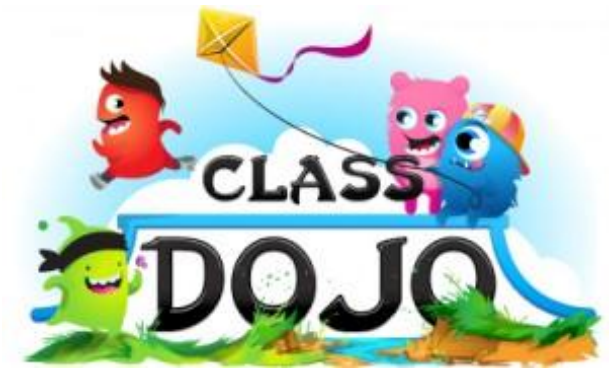

Gambar 1 Classdojo icon

Class Dojo (http://www.classdojo.com/) is a free classroom behavior management application that allows teachers to provide feedback to students about individual and group activities. This program can be operated through a computer or mobile device, making it easy to make classes motivated and focused by providing students with positive or negative feedback in the classroom by giving or reducing points for certain activities. Teachers can customize programs with badges, avatars, and specific activity characteristics for their programs. Because students receive feedback immediately, this application helps maintain student involvement and helps teachers in developing a positive and productive classroom learning environment(Hidayat et al., 2020).

Aplikasi ini menarik, karena aplikasi ini sangat ringan dalam hal penggunaan Kuota dan space di Smartphone dan Aplikasi Classdojo 100\% Gratis. ClassDojo adalah media pembelajaran interaktif antara guru dan siswa dimana guru fokus untuk memotivasi siswa dalam hal memberikan arahan dan pembelajaran dalam perilaku positif siswa yang bisa dibantu dan bisa melibatkan orang tua siswa dalam mendidik siswa. Guru bisa memberikan tantangan siswa melalui soal-soal dan latihan yang Rutin diberikan. tanggapan siswa akan secara langsung disusun Class Dojo lalu ditampilkan dan dikonversikan dalam bentuk perilaku/sikap. Nanti terlihat siswa yang rutin bersikap baik atau tidak, siswa ulet atau tidak, Kooperatif atau tidak dan lain -lain. Guru bisa memberikan nilai penghargaan atau peringatan pada setiap tingkah laku yang ditampilkan siswa. Aplikasi ini bisa juga dapat terhubung ke orang tua sehingga bisa membantu guru untuk mengawasi anaknya melalui portfolio atau nilai rangkuman pada setiap aktifitas yang diikuti anaknya. Untuk siswa, aplikasi ini memberikan peluang untuk lebih bisa mengapresiasi diri melalui berbagai kegiatan yang diikutinya, mulai dari berbagi hasil tugas, momen galeri baik foto atau video, dan lain - lain. Penggunaan aplikasi Class Dojo juga sangat mudah di pergunakan, Guru tinggal mendaftar, membuat akun, kemudian selanjutnya mengisi kelas-kelas dan nama siswa dan melakukan pembelajaran melalui kegiatan yang akan dilakukan dengan menunjuk siswa yang ingin di ikutsertakan. Masih banyak sekali fitur-fitur pendukungnya dalam pelaksanaan Pembelajaran Jarak Jauh. Jadi menurut pemateri aplikasi ini sangat cocok terutama untuk Sekolah Dasar yang memang menerapkan Pendidikan Karakter dan perilaku yang baik. 


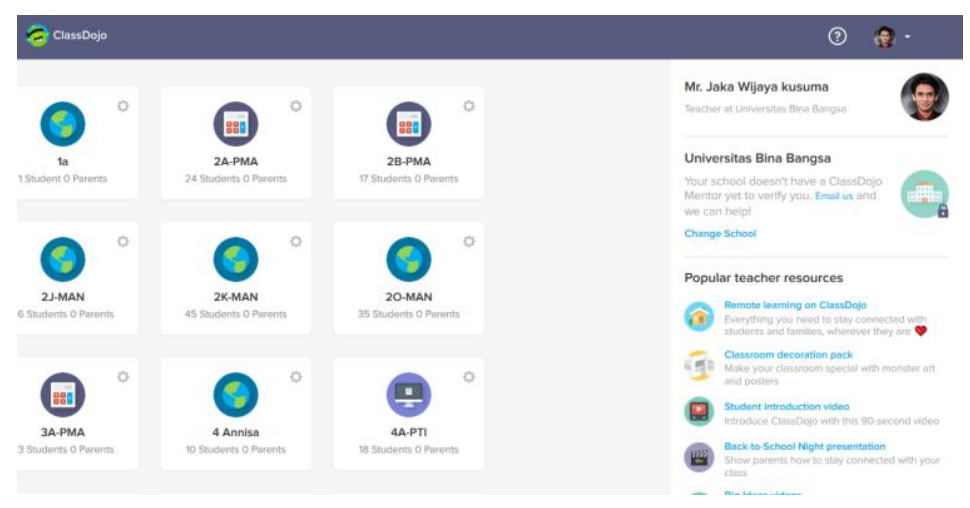

Gambar 2 Classdojo Tampilan Web

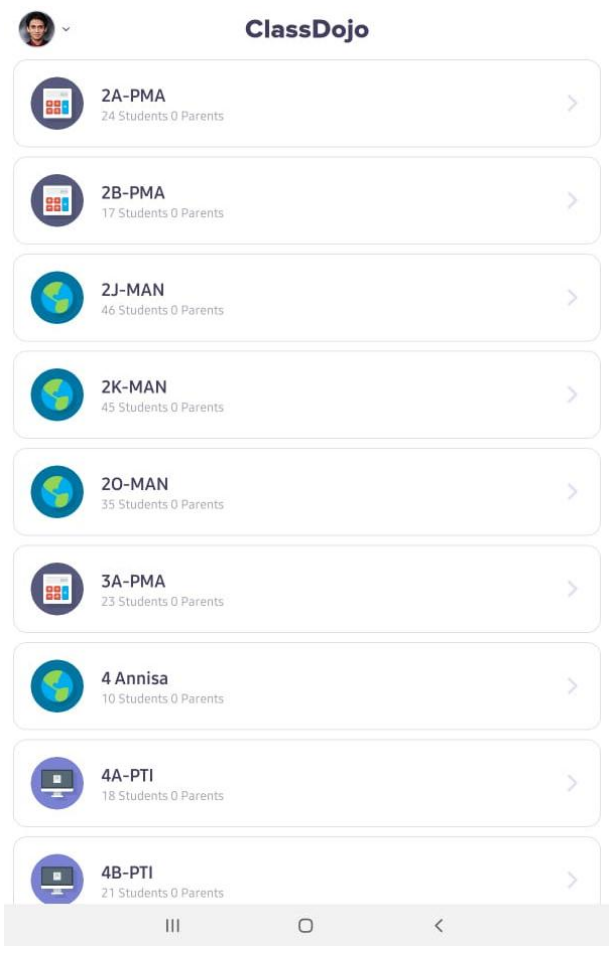

Gambar 3 Classdojo Tampilan Aplikasi

Clasdojo ada dalam 2 versi, yakni versi web dan versi Aplikasi. Dalam versi Web Guru bisa membuat kelas dan memasukkan siswa-siswanya kedalam kelas tersebut. Termasuk juga didalamnya untuk membuat laporan akhir disetiap akhir semester. Sedangkan dalam versi aplikasi di buat untuk pelaksanaan pembelajarannya. Di dalam aplikasi terdapat fitur lengkap dari classdojo yang dirancang untuk pembelajaran dan interaksi dengan Muridnya. Ada beberapa fitur aplikasi di antaranya memberikan Tugas, memberi Reward, memberi Punishment. Jadi kesimpulannya dalam versi web di buat untuk Perencanaan dan Pelaporan akhir semester, sedangkan versi aplikasi dibuat untuk pelaksanaan pembelajarannya. 
Pelatihan Penggunaan Aplikasi Classdojo Sebagai Upaya Peningkatan Pembelajaran Jarak Jauh Bagi Guru SD IT Bina Bangsa Di Era Kenormalan Baru ... (Jaka Wijaya Kusuma)

| 61-67
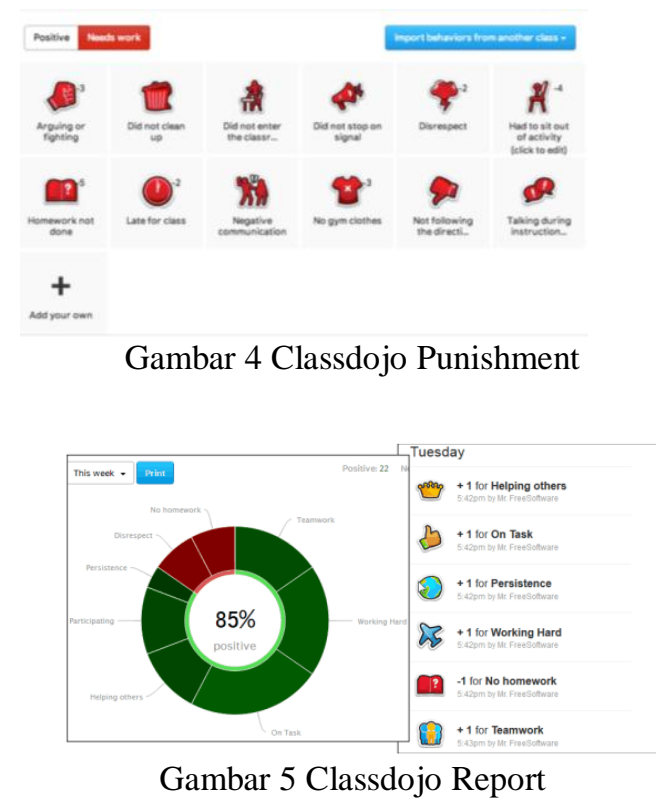

Aplikasi ini sangat sesuai dan sejalan dengan Landasan dari Pendidikan Sekolah Dasar, karena Siswa di arahkan dan di didik dari segi Perilakunya. Pendidikan adalah hal yang sangat penting bagi hajat manusia, maka perlu pelaksanaan yang sangat baik dalam pelaksanaan pendidikan agar hasil yang diperoleh sesuai harapan. Guru menjadi sangat penting dalam melakukan dan menegakkan pendidikan khususnya dalam mencerdaskan siswa-siswanya. Siswa adalah manusia yang masih dalam fase pertumbuhan, sehingga tiap perbuatan dan tingkah lakunya merupakan suatu bentuk bentuk timbal balik dari lawannya. Dengan kata lain, dalam proses pembelajaran siswa akan memperhatikan dan semangat mengikuti pelajaran jika guru memberikan feedback atau respon yang baik akan setiap keterampilan dan perilaku siswa(Kusuma \& Hamidah, hamidah; Sukandar, 2020). Berdasarkan permasalahan yang sudah disampaikan di paragraf-paragraf sebelumnya, maka penulis sangat tertarik untuk melakukan Pelatihan sebagai bentuk pengabdian kepada masyarakat dengan judul "Pelatihan Penggunaan Aplikasi Classdojo Sebagai Upaya Peningkatan Pembelajaran Jarak Jauh Bagi Guru Di Sd It Bina Bangsa Di Era Kenormalan Baru”.

\section{METODE PELAKSANAAN}

Pelaksanaan kegiatan pengabdian kepada masyarakat ini terdiri dari dua hari kegiatan, yakni hari pertama atau kegiatan pertama dalam bentuk sosialisasi pengenalan Aplikasi atau media pembelajaran apa saja yang bisa di gunakan dalam Pembelajaran Jarak Jauh dan hari kedua atau kegiatan kedua dalam bentuk Pelatihan langsung Praktek penggunaan Aplikasi Classdojo. Pelatihan penggunaan aplikasi classdojo pada guruguru SD IT Bina Bangsa di laksanakan pada hari Senin, 13 Juli 2020 di Lab Komputer SD IT Bina Bangsa Serang sedangkan untuk Pengenalan Sosialisasi Pengenalan Media Pembelajaran Jarak Jauh dilaksanakan 4 Hari Sebelumnya. Jumlah guru yang mengikuti pelatihan adalah 60 Guru. Dalam sosialisasi tahapannya hanya memberikan penjelasan secara umum terkait Platform Daring yang bisa digunakan, alternatif media pembelajaran yang bisa di pergunakan. Dalam Kegiatan ini tidak dikupas secara dalam di artikel ini, karena hanya berisi kegiatan Perkenalan aplikasi-aplikasi secara umum 
saja. Kemudian selang 4 hari selanjutnya dilaksanakan Pelatihan classdojo yang merupakan tahapan utama.Yang dilakukan dalam kegiatan pelatihan ini, yakni: 1) persiapan, 2) pelaksanaan, dan 3) evaluasi. Tahap persiapan dimulai melalui proses instalasi Aplikasi dan pembuatan Akun classdojo.Semua guru dipastikan berhasil dalam proses persiapan ini Apabila ada yang kesulitan langsung disampaikan dan dibantu. Tahap pelaksanaan dilanjutkan dengan memahami fitur-fitur yang dimiliki oleh classdojo dan pengoperasian classdojo secara detail dan langsung dipraktekan secara mandiri. Tahap pelaksanaan berupa penyampaian materi, praktik penggunaan oleh peserta. Dalam kegiatan pelatihan sesi tanya jawab mengalir antara pemateri dan peserta, serta praktik yang dilakukan oleh peserta. Pada proses praktik, peserta didampingi dan dipandu oleh pemateri dan tim pelatihan. Tahap akhir dari proses pelatihan adalah evaluasi hasil kegiatan. Instrumen yang sudah disusun pada Google Form kemudian diberikan kepada peserta pelatihan untuk diisi. Data hasil dari Google Form dianalisis menggunakan SWOT. Upaya untuk memperkaya data hasil pengabdian dilakukan dengan kegiatan wawancara kepada beberapa peserta pelatihan. Termasuk didalamnya menanyakan kepada guru kendala yang didapatkan selama menggunakan classdojo.

\section{HASIL DAN PEMBAHASAN}

Hari Pertama : Dalam Kegiatan ini, Semua guru atau peserta di kumpulkan di Aula dan pemateri memberikan materi terkait Media Pembelajaran Alternatif yang bisa di manfaatkan dalam Pembelajaran Jarak Jauh. Baik yang berbasis web maupun berbasis Aplikasi, baik yang Sinkron maupun yg asinkron. Seluruh peserta mengikuti kegiatan ini dan menyimak paparan dari pemateri. Tanpa ada praktek. Karena hanya menyampaikan secara umum dan bersifat memperkenalkan. Berharap peserta mau belajar secara mandiri dan mencoba beberapa Media Pembelajaran yang diperkenalkan oleh Pemateri.
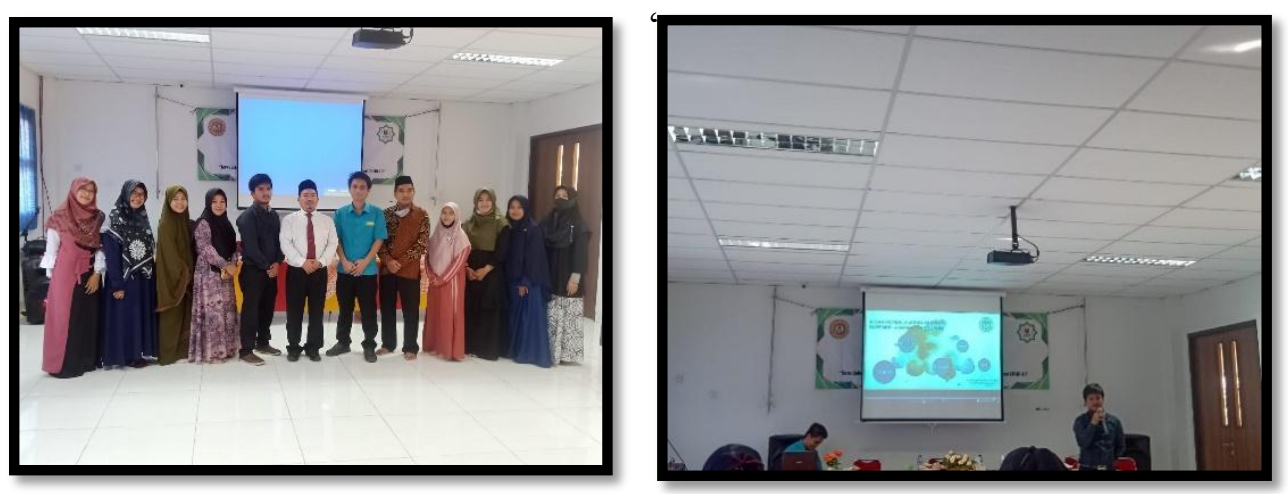
Pelatihan Penggunaan Aplikasi Classdojo Sebagai Upaya Peningkatan Pembelajaran Jarak Jauh Bagi Guru SD IT Bina Bangsa Di Era Kenormalan Baru ... (Jaka Wijaya Kusuma)

| 63-67

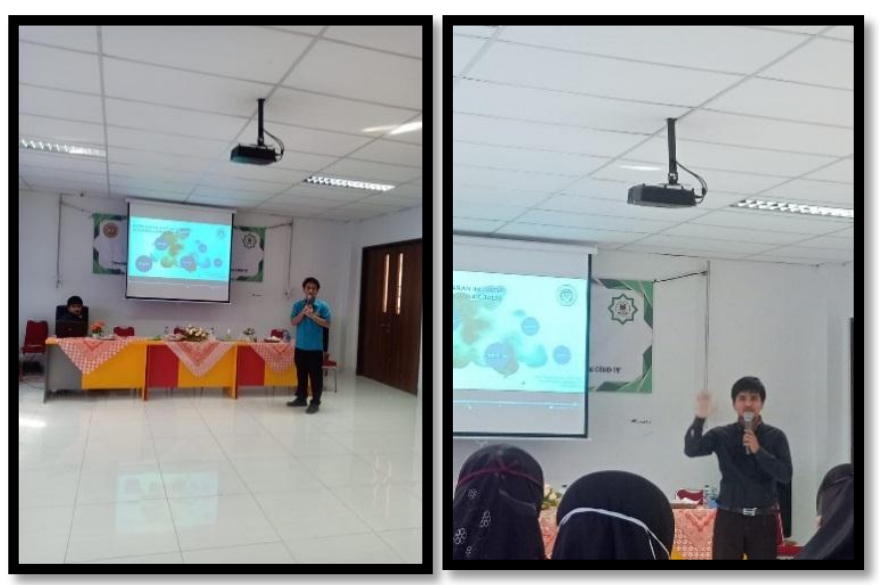

Gambar 6 Pertemuan Pertama

Hari Kedua : Di pertemuan kedua inilah, baru pemateri memberikan secara spesifik dan memberikan Pelatihan penggunaan salah satu Aplikasi Pembelajaran yakni aplikasi Classdojo. Dipilihnya aplikasi Classdojo sesuai dengan Permintaan Pihak Sekolah dan mayoritas Guru-guru peserta Sosialisasi di Pertemuan Pertama. Dalam Pertemuan kedua ini dibagi menjadi 3 tahap. Secara rinci dijelaskan Sebagai berikut :

1). Persiapan : Dalam tahap ini guru ditempatkan di Aula, dalam Pembuatan akun Classdojo kemudian dilanjut dengan Instalasi ke Perangkat Smartphone masingmasing Guru. Dalam tahapan ini tidak terlalu banyak kendala. Guru dipastikan mayoritas sukses dalam penginstalan dan pendaftaran Akun Guru. Hanya ada 2 guru yang terkendala ketika instalasi itupun dikarenakan space memory smartphone yang minim bukan karena kendala secara teknis di classdojo.
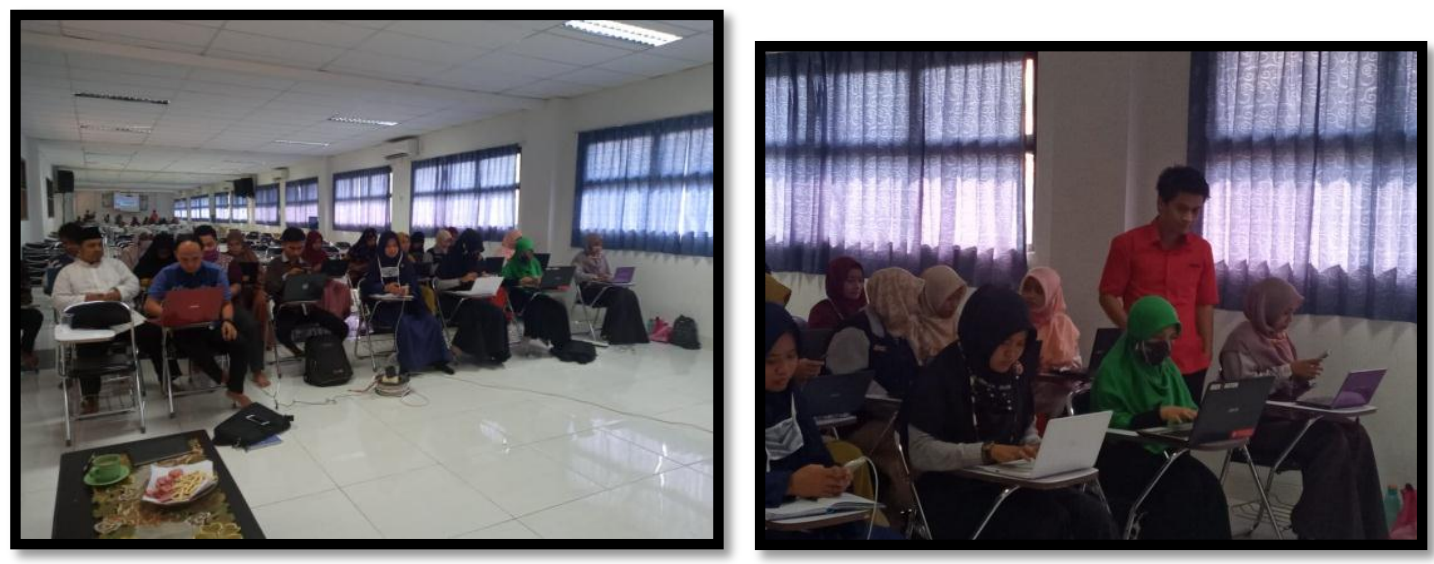

Gambar 7 Tahap Persiapan

2). Pelaksanaan : Dalam tahap ini, guru dipindahkan dari Aula ke Lab Komputer. Penyampaian materi dilakukan secara terstruktur, di berikan arahan secara step by step yang diawali dengan pengenalan fitur-fitur kepada guru. Sebelumnya Pemateri menjelaskan pentingnya Pengunaan aplikasi yang sesuai dengan karakter siswa dalam pembelajaran jarak jauh sehingga guru perlu inovatif. Salah satu platform yang bisa diterapkan adalah Classdojo. Alasan pemilihan Classdojo karena platform 
ini ringan kuota, Mudah pengoperasiannya dan bisa terhubung secara langsung kepada orang tua dan anaknya. Setelah itu, pemateri memulai menyampaikan beberapa fitur yang ada di classdojo dan langsung dipraktekkan oleh guru, diantara fiturnya disampaikan adalah mengundang siswa ke dalam kelas, mengisi absensi dan membuat instrumen tugas, Portofolio dan bagaimana melakukan penilaian dalam classdojo. Pada proses penyampaian materi terkait classdojo, peserta pelatihan terlihat sangat antusias. Hal ini dibuktikan dengan interaksi peserta yang bertanya kepada pemateri dan interaksi antar peserta yang saling bantu ketika ada yg kesulitan. Ini tentu merupakan respon yang mengindikasikan antusiasme peserta.
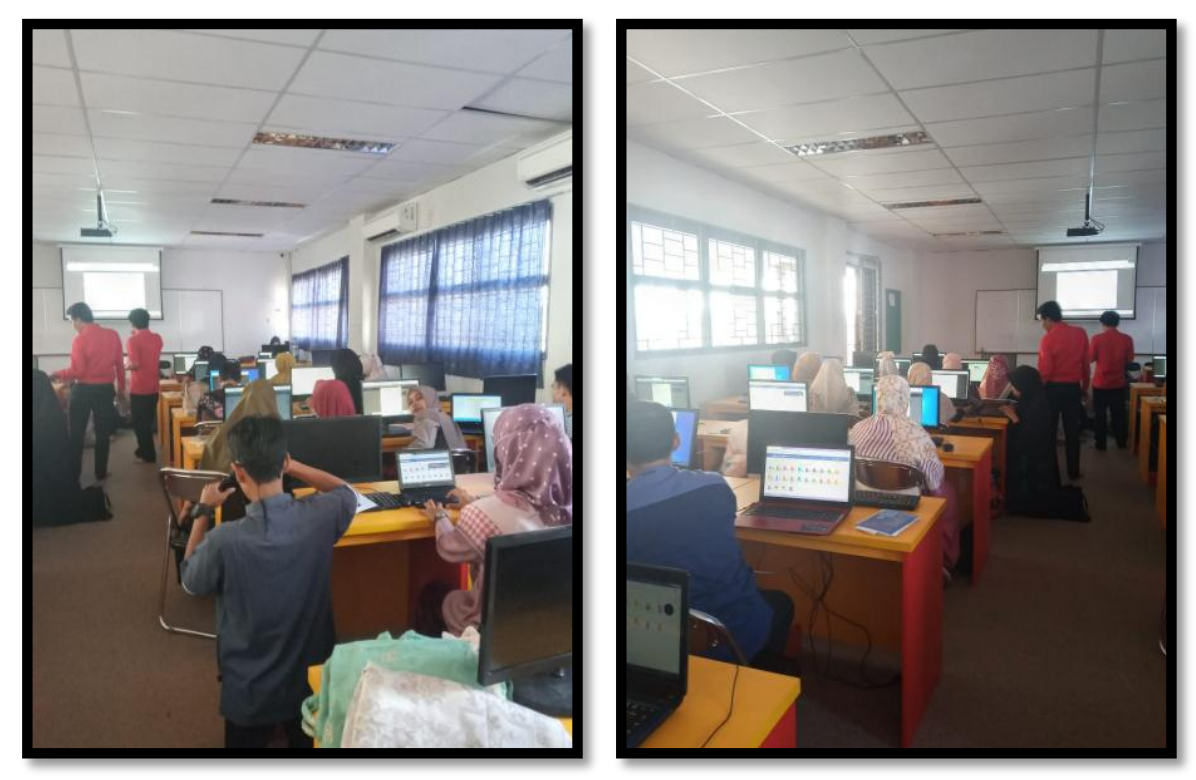

Gambar 8 Tahap Pelaksanaan

3). Evaluasi : Setelah dikenalkan dengan pembelajaran daring dalam penggunaan classdojo, ketertarikan untuk menjadikan aplikasi sebagai sumber belajar mulai terbuka. Umpan balik yang guru sampaikan dan isi di Google form banyak yang minta pendampingan lanjutan, paparan yang diberikan menambahkan wawasan tentang aplikasi Pembelajaran Jarak Jauh pada era kenormalan baru dan permintaan untuk mengkombinasikan dengan media lainnya seperti Kinemaster atau Camtasia. Beberapa hasil umpan balik yang disampaikan oleh guru di antaranya :

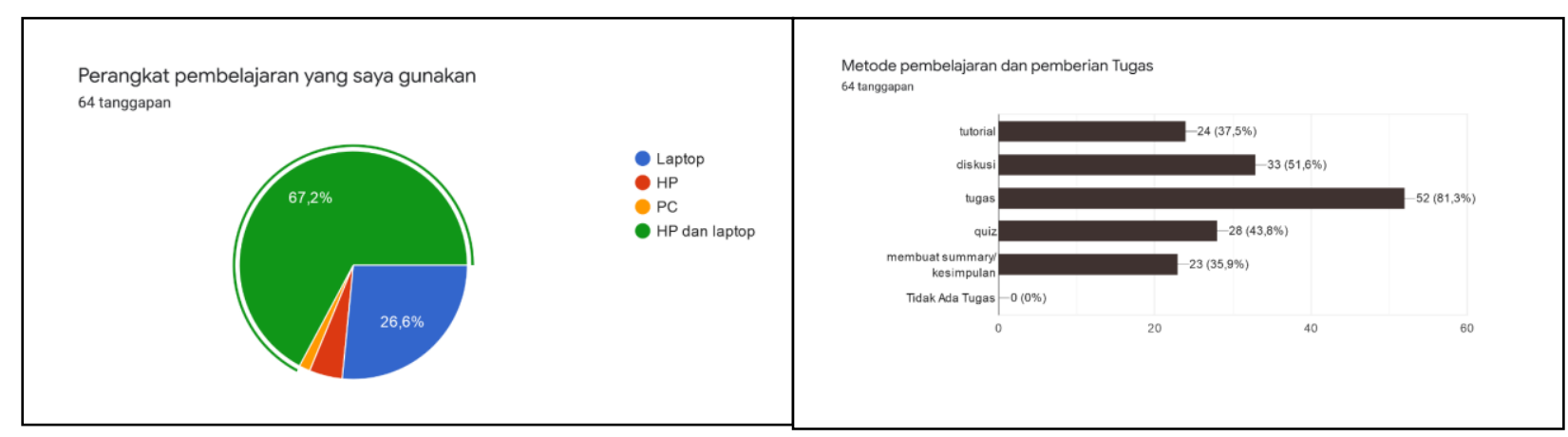


Pelatihan Penggunaan Aplikasi Classdojo Sebagai Upaya Peningkatan Pembelajaran Jarak Jauh Bagi

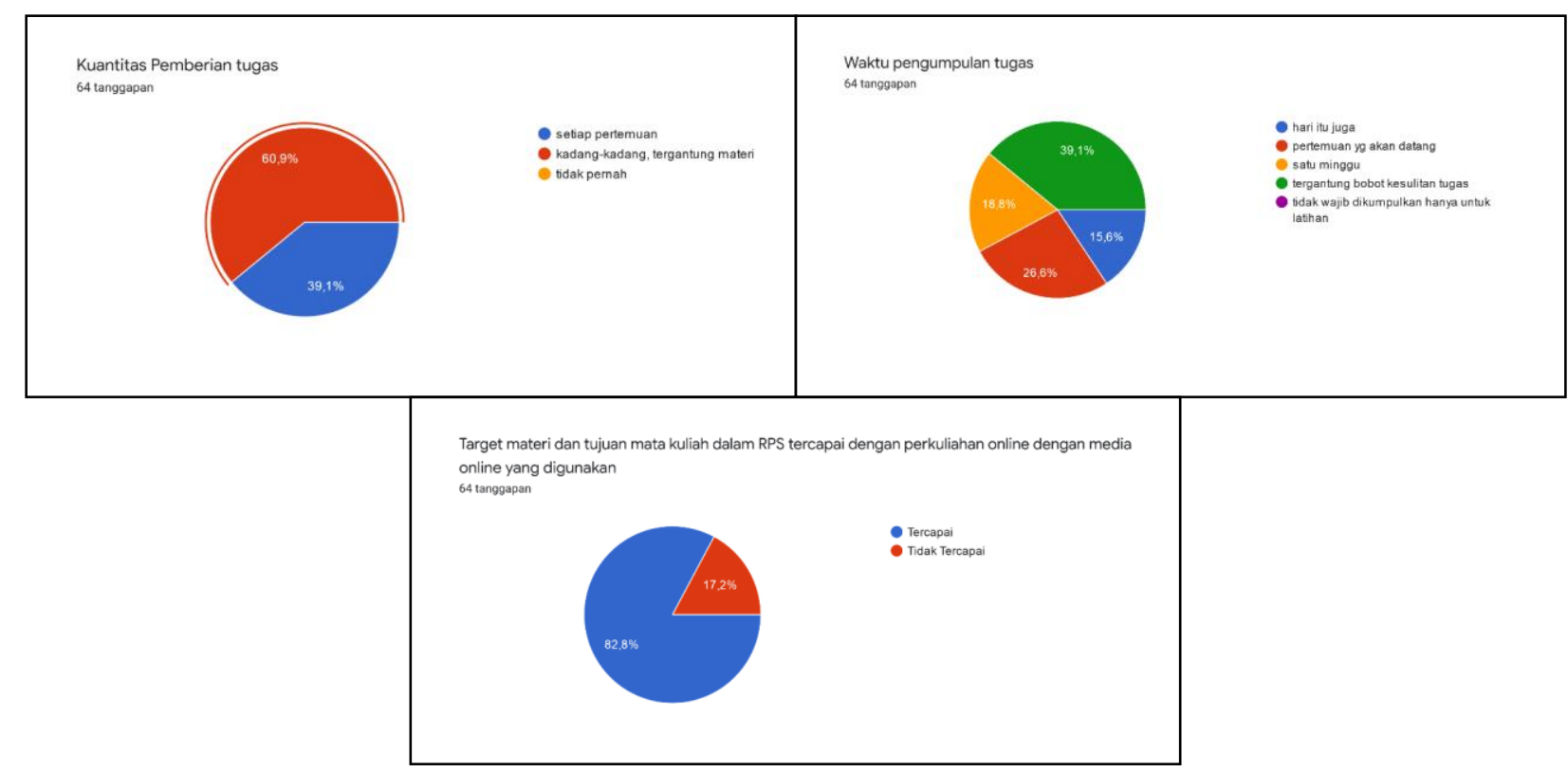

Gambar 9 Umpan Balik Kegiatan

Hasil Umpan balik di atas menandakan masalah dan kendala yang di alami guru, mulai dari kesiapan perangkat, metode yang digunakan sampai ke pemberian tugas dan kesuksesan di target pencapaian. Dengan adanya Pelatihan ini, setidaknya guru diberikan alternatif media yang dapat digunakan dalam proses belajar dari rumah. Sehingga bisa memaksimalkan dalam hasil pencapaian dan daya serap Mata Pelajaran yang diberikan.

Kemudian di tab berikutnya, guru atau peserta di arahkan untuk mengisi form untuk menilai kegiatan pelatihan ini, mulai dari pemateri, moderator, dll. Hasil umpan balik bisa dilihat berikut :

Bagaimana tanggapan Anda tentang materi Workshop ini secara keseluruhan?

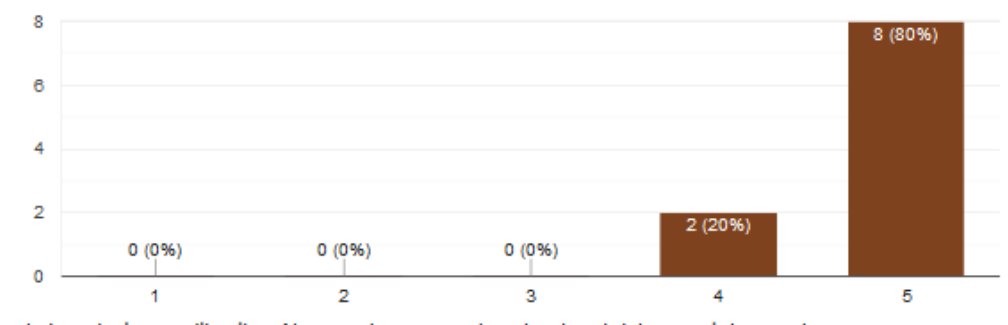

Apakah materi yang diberikan Narasumber secara keseluruhan telah sesuai dengan tema Workshop?

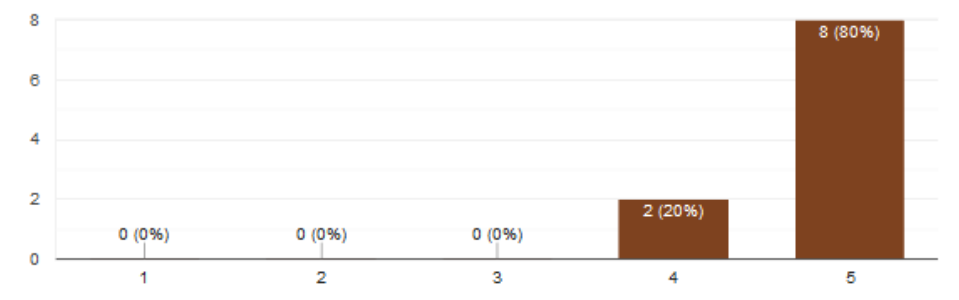




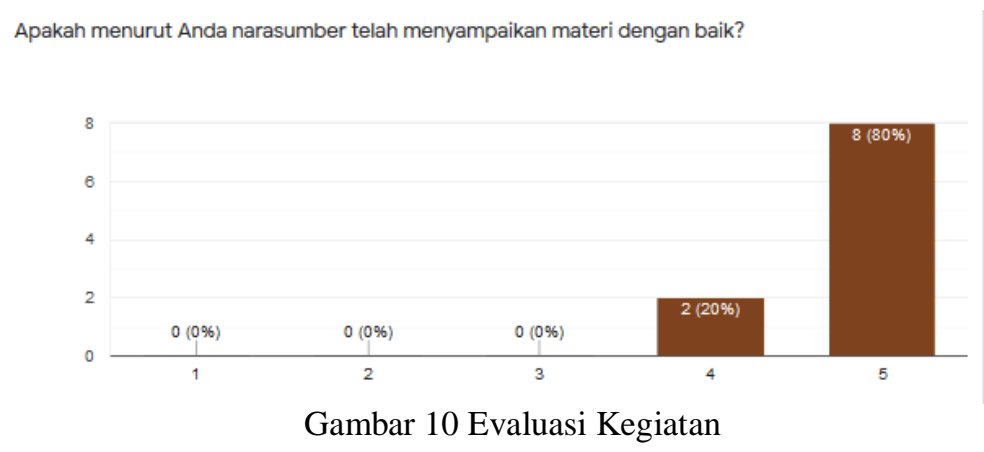

Hasil Umpan balik diatas menandakan guru menerima dengan baik Pelatihan ini. Pelatihan ini mudah dipahami guru. Dan dari beberapa Kritik dan saran yang masuk, Guru mayoritas mengharapkan ada kegiatan lanjutan pelatihan ini. Seperti bagaimana menjadi Tutor atau Advisor Classdojo secara resmi.Ketertarikan ini merupakan sinyal kuat bahwa Guru sangat ingin mendalami aplikasi ini dan membagikan kembali ke rekan-rekan lain. Dalam menanggapi hal ini, Pemateri mengumpulkan guru kedalam satu Grup Whatsapp yang khusus dibuat untuk tindak lanjutan pertanyaan yang lebih spesifik dan media komunikasi selanjutnya.

\section{SIMPULAN}

Berdasarkan hasil dari kegiatan pelatihan ini dan sebagai pengabdian kepada masyarakat, maka dapat diketahui bahwa dari 60 orang guru SD IT Bina Bangsa mayoritas sudah menerapkan pembelajaran online. Terlihat dari penguasaan aplikasi dan daya serap ketika pemateri memberikan Tutorial, peserta sangat cepat mempraktekan ulang, Selain itu, banyak guru juga mahir dalam membuka web, menggunakan internet dan instalasi aplikasi.

Pelaksanaan pelatihan berjalan dengan baik dan peserta antusias dalam proses penyampaian materi serta praktik. Hasil evaluasi kegiatan menunjukkan bahwa guru sangat tertarik akan aplikasi classdojo ini. Terutama agar bisa di terapkan di Pembelajaran Jarak Jauh. Selain itu, berdasaran hasil timbal balik dari peserta, pelaksanaan pelatihan ini memicu Peserta atau guru untuk lebih jauh lagi mengenal classdojo. Hal ini ditunjukkan dengan penilaian pemateri yang mencapai $80 \%$ sangat baik, workshop $80 \%$ sangat baik, dan kejelasan materi juga $80 \%$ sangat baik,

Berbagai saran yang perlu ditindak lanjuti dan bisa diterapkan di pengabdian lainnya yakni: 1) pelatihan penggunaan pembelajaran online classdojo dan mengkombinasikan menggunakan platform yang lain, 2) bukan hanya pembelajaran online saja, namun peserta bisa menjadi Advisor atatu tutor classdojo sehingga meningkatkan kompetensi profil guru-guru, 3) kualitas pelatihan dan pendampingan perlu tingkatkan lagi terutama dari segi durasi waktu yang diberikan.

\section{DAFTAR PUSTAKA}

Hidayat, H., Mulyanto, A., Hermawati, Y., \& Nusantara, U. I. (2020). Class Dojo As Indonesian Language Learning Media At Senior High School. https://doi.org/10.4108/eai.20-9-2019.2290953 
Pelatihan Penggunaan Aplikasi Classdojo Sebagai Upaya Peningkatan Pembelajaran Jarak Jauh Bagi

Kurniawan, B., Purnomo, A., \& . I. (2020). Pelatihan Penggunaan Aplikasi Google Classroom Sebagai Upaya Peningkatan Pembelajaran Online Bagi Guru Matapelajaran IPS MTs Di Kota Malang. International Journal of Community Service Learning, 4(1), 1. https://doi.org/10.23887/ijcsl.v4i1.22236

Kusuma, J. W., \& Hamidah, hamidah; Sukandar, R. S. (2020). Penguatan Pembelajaran Matematika Siap Menghadapi Ujian Dengan Model Pembelajaran Assurance-Relevance-Interest-Assessment-Satisfaction Di Yayasan Nurul Falah Talok Tangerang. JURNAL ABDIDAS, 1(4), 193-202. https://abdidas.org/index.php/abdidas/article/view/43/33

Kusuma, J. W., \& Hamidah. (2020). Perbandingan Hasil Belajar Matematika Dengan Penggunaan Platform Whatsapp Group Dan Webinar Zoom Dalam Pembelajaran Jarak Jauh Pada Masa Pandemik Covid 19. JIPMat, 5(1). https://doi.org/10.26877/jipmat.v5i1.5942

Sobiruddin, D. (2020). Pendampingan Bagi Guru RA Di Pandeglang Banten Dalam Memanfaatkan Media ICT Berbasis Proyektor Interaktif. Wikrama Parahita, 4(1), 13-20. 